Review Articles

\title{
Intuition, Luck and Misfortune in Diabetes Research*
}

\author{
A. Labhart \\ Medical Clinic, Department of Medicine, University of Zürich, Zürich, Switzerland
}

Key words: Intuition, serendipity, diabetes research, kairos, techne: knowledge and ability, tyche: favourable and unfavourable fate.

The history of diabetes mellitus is a paradigm of factors determining the outcome of research: success or failure. Logical thinking and intelligence, interest and inquisitiveness, perseverance and steadiness, technical ability, experience and information are indispensable for a potential success.

Yet neither in art nor in science does something really new ever result from knowledge and ability alone. There is no creative achievement without irrational phenomena such as: inspiration, intuition, imagination - phenomena which need, however, to be tested by critical thought and practical experience. Most discoveries are the result of logical thinking and favourable circumstances; yet without intuition and creative ideas research never gets off the barren track. In the present scientific literature the greatest part of the results is estimated to be redundant or obsolete. "When princes are building, hacks are busy." Besides the irrational - in science even more than in art - a third factor is important: a favourable constellation of environment, matter and time something over which the researcher has no command. At his best he may sense and grasp the right moment.

In ancient Greece the Sophists distinguished between techne and tyche. Techne: knowledge and ability, tyche: fate, destiny - a power beyond our reach.

* The Paracelsus Lecture delivered on September 25, 1977 before the European Association for the Study of Diabetes at Geneva, Switzerland
Research therefore may be compared with an adventure. Like a sailor setting out to unknown seas and territories - a comparison dear to Joslin, the dean of modern diabetology - the researcher does not know whether he will reach his goal or whether he will have to turn back.

Closely linked with tyche is kairos - a notion only to be found in ancient Greek, meaning: the right moment, proffered or withheld by tyche, and which must be seized.

During the Renaissance the notions of techne and tyche were revived as virtus and fortuna and it was no lesser man than Paracelsus himself who wrote the pamphlet: "Liber de bona et mala fortuna" [20].

Philippus Theophrastus Bombastus von Hohenheim (1493-1541), called Paracelsus, was born in Einsiedeln near Zurich. At the zenith of his career he was a town physician in Basle, after he had travelled through Europe from Scotland to Greece, from Poland to Spain. Ten years later, a man of 45 , he was disappointed, embittered, expelled from Basle, wandering again restlessly through Europe, a man old before his time. He may be considered as the father of modern medical science, for he broke with hypothetical, unproven dogma of Celsus and Galen which had been transmitted to the Middle Ages by the Arabs. Paracelsus found a new base of medicine founded on experiments. He declared war in Basle against traditional medicine, much to the displeasure and even rage of a faculty persisting in scholastic brooding. He certainly must have been one of the outstanding Renaissance personalities, full of contradictions: at one time the great Prince of science, the physician with yet unattained successes; at another humble with the poor, careless of himself, negligent and given to drinking. Specific observations are sometimes rationally explained, sometimes mystically and on the basis of faith. His scientific 
approach to medicine - unlike that of Harvey, Vesalius or the Italian, French, English and German doctors of the 18th and 19th Century - may therefore be assessed only in a limited degree as natural science. His greatest achievement was probably the introduction of chemical methods into medical diagnosis and therapy. He may be called the founder of medical chemistry.

Whereas since Aretaios the diabetic symptoms such as polyuria, polydipsia and emaciation were known and had been attributed since Galen to a disease of the kidneys [23], Paracelsus considered diabetes - though he did not use the term - as a general disease caused by an alteration of the composition of the blood "which must contain a dry salt" and he classified it therefore among the "tartaric" or metabolic diseases [20].

Paracelsus would speak of a "dulcedo" in the urine, without, however, implying a taste as sweet as sugar (Seckendorf, 1931). "Dulcedo" meant in the alchemistical notions of those days that the urine had neither an acid nor an acrid smell. According to Schadewaldt [23] and Papaspyros [19] it seems quite possible that Paracelsus trying to obtain a salt by evaporation of diabetic urine found residues of glucose, which he failed to recognize.

Here we have a first example of how results obtained by a valid new method are not appropriately interpreted. Though he advised testing the urine with the tongue he failed to try the flavour of the residue of the evaporated urine and mistook it for saltpetre. Absence of intuition: kairos was at hand, but he did not grasp it.

Mala fortuna? I hoped to find in his "Liber de bona et mala fortuna" some thoughts on favourable or adverse conditions in research, but it is a rather trite, moralizing if not pietistic treatise, which denies luck and misfortune sub specie aeternitatis.

Our compatriot Johann Conrad Brunner from Schaffhouse, later in Düsseldorf and professor in Heidelberg, was similarly on the verge of a great discovery, and failed to recognize it [23]. He tried to elucidate the importance of the pancreas in the organism of animals by ligatures and extirpations of the pancreas. His partial pancreatectomy which induced polyuria and polydipsia in a dog should have made him think of searching for glucose [23]. Yet Brunner was convinced he had shown that the pancreas was a non-essential organ. Here too techne was present, but the key that only tyche could give, was missing. Willis (1621-1675) was apparently the first to test the urine of diabetics with his tongue and to recognize glucosuria as the source of polyuria, but he attributed it to kidney damage.

This is not the place to go into all the correct observations and discoveries, or all the wrong tracks in the history of diabetes. Schadewaldt has written a competent and exciting history of diabetes [23] out of which I have taken most of the here quoted examples. Our object is to investigate why - being within reach of their goal - success was denied to some researchers and granted to others.

To illustrate this investigation I have chosen two examples: one is Minkowski's discovery of pancreatic diabetes, the other Zuelzer's detection of insulin, the importance of which he failed to recognize.

Oskar Minkowski and the Freiherr von Mering worked together under Naunyn in Strasburg. Shortly before, von Mering had discovered Phlorizin-diabetes. The two young researchers investigated intestinal fat resorption and examined the influence of the pancreas on it. Since von Mering didn't succeed by ligating the pancreatic duct, Minkowski, an able experimenter, proposed the extirpation of the pancreas. No sooner said than done. The dog recovered from the operation, but the animal, hitherto housetrained, repeatedly urinated in the room and made life difficult for the laboratory servant. Minkowski, under the influence of a sudden inspiration examined the urine and found a high percentage of glucose. He repeated the same experiment with several dogs, and every time found a severe diabetes. A blood-transfusion from a diabetic to a healthy dog didn't produce a diabetes which excluded a toxic effect.

Polyuria and polydipsia had been reported to Minkowski by the animal keeper - an observation already registered by Brunner 200 years before. The creative achievement of Minkowski lies in his association: polyuria equals glucosuria. Here, intuition had worked.

At the same time Minkowski's discovery is an illustration of serendipity: the faculty to search for one thing and to discover another.

The three elements: techne: exceptional skill for experiments, knowledge and ability; tyche: the possibility of experimenting on animals, as well as intuition and finally luck and serendipity have contributed decisively to elucidate this enigmatic disease diabetes. Claude Bernard's hypothesis of angioneurogenic diabetes was finally disproved by Minkowski's discovery. The pancreatic origin of diabetes was now established.

Twenty years later kairos bypassed Minkowski. In his clinic in Breslau his disciple Forschbach [7] was working on diabetes with the pancreatic extracts of Zuelzer. Blood sugar was reduced, acetone disappeared, but Forschbach abandoned his experiments with this extract because of toxic side-effects. In 1929, Minkowski said that he could never forgive himself for having abandoned his endeavours to investigate the causes of the side-effects of these preparations considering their unquestionable influence 
on glucosuria. And I quote Minkowski: "We have just limited ourselves to stating their therapeutic uselessness in men" [18].

Georg Ludwig Zuelzer (1870-1949) was not the first one trying to extract a substance from the pancreas which would prevent diabetes. Table 1 lists the names of researchers attempting, with varying degrees of success, to extract diabetes-preventing substances from the pancreas. It shows how, between 1892 and the first World War this goal was lying almost within reach. All of them gave in with the exception of Zuelzer, who, for 12 years doggedly pursued his idea and yet at the end fell short. He had the substance - the Acomatol, as he called it - in hand, yet he didn't dare to make use of it because of the misinterpretation of its effects.

Zuelzer had been inspired by the discovery of pancreatic diabetes, but devised a theory of pathogenesis on the basis of the adrenaline-diabetes described by Ferdinand Blum in 1901 [2]. He could demonstrate that injections of adrenaline caused a rise of blood sugar and led to glucosuria.

Ferdinand Blum (1865-1959), an original personality, was possessed up to a very old age by an intense ardour for research. A good skier until 85, at the age of 93 he was still sitting at his desk until 3 a. $m$. Of Jewish descent, he was obliged to flee from Germany at the age of 70 . He settled then in Switzerland where he continued to live for research, working occasionally for the pharmaceutical industry. When I met him 20 years ago he was even then, eager to explore the mechanism of the hypoglycaemic effect of the sulphonylureas and we did in our laboratory some experiments he wished to do. Alas, though at the age of 93 his mind was still imaginative and creative, the hypotheses it produced were often queer, improbable and they all proved to be wrong. But his enthusiasm was impressive: for a talk on diabetes problems he invited me to his home for a typical German old fashioned "Kaffee mit Kuchen", and after a long, lively discussion he finally said: "Good Lord, what would I give to be 80 once more. What projects could I explore. But you know, at the age of 93 one must think about finishing one's life's work". It was a year later, in 1959, that he died. But in 1901, Blum had performed some crucial experiments on the relationship of the adrenals and glucosuria. $\mathrm{He}$ injected a watery extract of adrenals into rabbits and dogs and observed regularly hyperglycaemia and glucosuria up to $1 \%$ and of 1 to 3 days duration. He repeated these experiments with the then available adrenaline preparations and he concluded that this suprarenal extract was toxic in some way; that this kind of suprarenal diabetes had nothing to do with pancreatic diabetes but rather that Claude Bernard's puncture would act by stimulation of the adrenals.
Table 1. Experiments of insulin extraction before Banting and Best

\begin{tabular}{llll}
\hline Capparelli & 1892 & Pratt & 1910 \\
Comby & 1892 & Leschke & 1910 \\
Battistini & 1893 & Scott & 1911 \\
Vanni & 1895 & Hedon & 1911 \\
Blumenthal & 1898 & Murlin u. Kramer & $1913-1916$ \\
Zuelzer & $1903-1914$ Kleiner u. Meltzer & $1915-1919$ \\
Gley & 1905 & Paulesco & $1916,1920-21$ \\
\hline
\end{tabular}

Nevertheless, Zuelzer, his friend and collaborator, brought up the theory that the real diabetes was due to an imbalance between adrenaline and its antagonist insulin. A fatal hypothesis that hindered him from thinking of hypoglycaemia as an effect of insulin overdosage and from recognizing the convulsions of his treated dogs as a powerful effect of his extract.

In those days, the idea of internal secretion was not yet widespread. Though Laguesse [14] presumed an internal secretion of a cell group, termed on his suggestion "Langerhans islets" - most of the researchers, like Blum - believed a toxic substance to be the cause of diabetes, a substance detoxified in the liver by pancreatic secretion. For 12 years, Zuelzer was working on the extraction of an antidiabetic hormone of the pancreas - a hypothetical antagonist of adrenaline. Three patent privileges in Germany, England and the United States were the results of these endeavours.

Why then had Zuelzer fallen short of his goal by a hair's breadth? Why had insulin not been available 10 years earlier? Thousands of diabetics could have been saved from coma and a premature death. Techne: knowledge and ability had been at hand, likewise an unequalled perseverance. And intuition? The wrong hypothesis based on the perfect experiments of Blum had kept Zuelzer from recognizing insulin as a regulator of blood sugar, he had supposed it to be merely a neutralizer of adrenaline. The symptoms of hypoglycaemia were in those days not yet known.

Tyche? The measurement of blood sugar by micro-methods was not yet known. Zuelzer, nevertheless, had carried out measurements of blood sugar, but neither on persons nor on his dogs in convulsions. But tyche proved to be adverse: envious and jealous colleagues, no official academic position. Moreover his application for a grant to work at Dohrn's Zoological Institute in Naples with isolated islet cells of seafishes was flatly refused. A cooperation with the firms of Schering and Hoechst came to nothing. Finally, Hoffmann-La Roche put a gifted chemist, Camille Reuter, student of the Nobel prizewinner Wilstätter, at his disposal. He extracted 
$114 \mathrm{~kg}$ of pancreas in the laboratories of HoffmannLa Roche. The director, Emil Barell, was favourable to the project and is reported to have said, that the prestige of his firm demanded the support of this work in a new scientific field, though the results might not be of practical use, a really outstandingly far-sighted attitude of the manager of a firm dependent on financial profit. Reuter purified the extracts as far as possible and in 1914, Zuelzer had in hand an extract which was powerful and highly purified and with which he carried through a series of successful though tragically misinterpreted experiments on dogs. Their excessive convulsions must have been caused by hypoglycaemia but Zuelzer believed them to be the toxic effect of the copper from the vessels, in which the glands were extracted.

But he didn't give up, he wanted to go on. But then tyche dealt him the hardest blow of all: the outbreak of the First World War. His clinic was converted into a military hospital and he left for the front - and this was the end of his research on diabetes.

Similar was the fate of the Roumanian Paulesco. He too had an effective though less purified preparation at his disposal. His publication was delayed for years by the First World War and only came out shortly before the publication of Banting and Best [23].

A little later, thanks to knowledge and fate, the Canadians finally reached the goal.

During the discovery of sulphonylureas intuition and serendipity reappeared three times. At the beginning, destiny was not favourable to Loubatières and Janbon either. The Second World War prevented the distribution of their publications, though Loubatières later received due credit. The observations of Kleinsorge, Carstens and Haack remained unknown outside Eastern Germany. But fate was well disposed towards Franke and Fuchs to which tyche gave the break-through [23].

If we venture an outlook on the development in diabetes research I should like to mention NSILA, an insulin-like growth factor, which has been the subject of research in our Zürich group for the past 15 years.

One of the first puzzling observations was that serum contains 15 to 20 times as much bioassayable as immunoassayable insulin. The insulin antibodies of the guinea pig suppress the biological activity of insulin but not that of serum, hence nonsuppressible insulin-like activity (NSILA). After many drawbacks the growth-promoting activity of this substance was established, and Humbel has lately succeeded in sequencing the whole polypeptide hormone. The amino acid sequence of insulin and NSILA shows considerable homology and the 3 disulphide bridges are placed in the same positions. Does this mean that the two hormones have a common ancestor and was it sheer chance that one of the two developed into NSILA? Is NSILA just an interesting polypeptide or an important physiological hormone? Could the comparison of the two hormones help peptide chemists to develop smaller peptide hormones with the biologically active centre? We still don't know whether or not tyche shall be favourable.

After these few side-lights on the history of diabetes I would like to consider some thoughts about the factors leading to success, which I mentioned at the beginning. "The way of an investigator" by the Bostonian physiologist Walter B. Cannon [4] is probably the best and most readable book written on modern biological research.

Strangely, he doesn't mention the notion of intuition, though he wrote a whole chapter about it, with the title "The role of hunches". The phenomenon of the flash of ideas he calls "hunch", a word meaning originally a push or thrust. In ordinary experience it means the quick gleam of a suggestion that flares up unexpectedly as the answer to a difficult question or explanation of a puzzle, or in other words, the "Heureka" of Archimedes.

Cannon considers it to be an extraconscious process and quotes many examples of important discoveries by "hunches", coming during dreams or sleepless nights.

Another remarkable contribution to our insight into the nature of intuition in science has been made by the internist Gross of Cologne [8].

It is fascinating to enquire into the origin of the notion called intuition, which, from Antiquity through the Middle Ages up to the present has absorbed the attention of philosophers, theologians, psychologists, psychiatrists and still does. Intuitio is derived from the Latin intueri (to look at) - contrary to invenire which has the meaning "to come across" or "to discover" something consciously. "Epibole" has in ancient Greece the significance of a "sudden grasp". The later Greek philosophers distinguished already between intuitive and discursive comprehension. Related to it is Platon's "Daimonion", that inner voice which prevented Socrates from speaking inappropriately or acting unjustly.

In scholastic philosophy "intuition" has the meaning of divine revelation and miraculous vision. For the mystic Nicolaus Cusanus "intellectualis" intuitio is the highest level of knowledge and the notion of intuitio plays an essential role in Spinoza's philosophy.

With the beginning of modern times God is no more recognized as a source of transcendental insight in philosophical definitions, but for Descartes too intuitus absolutely denotes the original and unique knowledge, the undemonstrable aeternae veritates [8]. Intuition stands for a spiritual insight with Leib- 
niz as well as with Kant and Schopenhauer, who said: "It must be concluded that the discursive or deductive methods of the consciously logical thinking signifies hobbling along on stilts, whereas the logic intuition may be compared to Pegasus' flight of the unconscious which leaps in a flash from earth to heaven". In the philosophy of the 20th Century intuition takes a central position like in that of Husserl, in the philosophy of Bergson.

For Bergson [1] a close relation exists between intuition and instinct, - the innate faculty for preconscious and appropriate action as it is inherent in animals, primitive human beings and infants preceding the dawn of conscious thought. Bergson defines intuition as an instinct become conscious [17].

As instinct is opposed to thought, intuition is the faculty of recognition outside the conscious process of reasoning.

The biologist Max Hartmann - in "Die philosophischen Grundlagen der Naturwissenschaften" - acknowledges on the basis of Nicolai Hartmann's theory of cognition that, besides deduction and induction, analysis and synthesis, particular facts and various natural laws may suddenly be brought into a synthetic connection without the assistance of a logical or rational integration (Gross, 1975).

Finally Benedetto Croce sees intuition as closely connected to the creative and intellectual activity of man.

Now, attempts are being made to interpret intuition on a neurophysiological basis as a kind of diverse combination on the borders of memory $[5,8]$.

For we physicians, however, the description of Carl Gustav Jung [11] is of unequalled lucidity and importance. He classes intuition with the four basic functions: thinking, feeling, sensation, intuition. He defines it as a perception via the unconscious. It may concern either objects or relationships. It has nothing to do with meditation, feelings, or intellectual conclusions. Intuition is an irrational function of perception and is, alongside sensation, a characteristic of infantile and primitive psychology.

Closely related to intuition is the faculty to grasp aspects in analyses and experiments not planned beforehand. Chance may play a role here, but there has never been any creative achievement by mere hazard. Intuition is needed to grasp the significance of kairos. Pasteur wrote: "Dans les champs de l'observation le hazard ne favorise que les esprits préparés" [21]. For this kind of occurrence AngloAmerican science has rediscovered the expression "serendipity". This word was for the first time used by Sir William Osler; according to Cannon it can be traced back to Horace Walpole (1754).

In 1754, Horace Walpole in a chatty letter to his friend Horace Mann proposed to add a new word to our vocabulary, "serendipity". Walpole's proposal was based upon his reading a fairy tale entitled. "The three Princes of Serendip". Serendip was the ancient name of Ceylon. "As their Highnesses travelled", so Walpole wrote, "they were always making discoveries by accident or sagacity of things which they were not in quest of." When the word is mentioned in dictionaries, therefore it is said to designate the happy faculty or luck, of finding unforeseen evidence of one's ideas or, with surprise, coming upon new objects or relations which were not being sought."

Cannon gives various examples of unexpected discoveries in research, among them the discovery of the pancreatic diabetes by Minkowski and the all too familiar history of the discovery of penicillin by Sir Alexander Fleming.

Closely linked with intuition is the grasping of the right moment; the kairos for the ancient Greek. With their early poets Hesiod and Pindar it meant the favourable moment granted by nature and the gods to mortal man, promising success and prosperity. This idea became sacred and in Olympia a cult grew up around the statue of Kairos. The original by Lysippos is lost, but Roman replicas exist. He is represented as a youth with wings on his shoes like Hermes wearing a fore-lock which must be seized without hesitation. The notion is also well known through the writings of Hippokrates:

"Art is long, life is short, the right moment (kairos) fleeting, experience may deceive, human judgement is fallible."

or

"In the course of a disease the right moment may suddenly be at hand - but if it comes it will not linger."

If on the one hand recognition of kairos and action are required, on the other hand the notion includes an element of tyche, and only those favoured by destiny will recognize and seize it.

And this brings us finally to the notions of luck, misfortune and chance -- which - besides knowledge, ability, perseverance and intuition - are indispensable for success in research. Among circumstances favourable to research Cannon mentions factors such as: personal freedom, security, possibility of communication and among those adverse to it: a hostile atmosphere, jealous colleagues and finally war.

Of these external circumstances the researcher has no command, they are beyond his reach. Hence, research is an enterprise the outcome of which is unpredictable and therefore courage to risk and even to err is necessary [6].

Banting and Best were in comand of techne, but tyche too smiled upon them. They had loyal colleagues and a professor of physiology, who, though 
sceptical, not only allowed inexperienced Banting to experiment, but put the hard-working student Best and the gifted chemist Collip at his disposal - and they got hold of kairos. To Zuelzer on the contrary the favour of destiny was denied. Techne was at hand, tyche was adverse and kairos left him behind. Within a year - an unbelievably short time - the Canadians produced an insulin without any side-effects, which saved the lives of innumerable diabetics hitherto condemned to a premature death.

Techne and tyche are determining factors of our work. Techne, not difficult to comprehend, has become almost an idol of our time and Professor Löffler, my pre-predecessor, used to show to his students a statue of Asklepios with his servant Telesphoros, the little god of technical skill, saying that he hoped Telesphoros would never outgrow the great Asklepios. Whereas tyche is according to the Berlin philosopher Landmann a "scandalon" for philosophy [15]. "It cannot be reduced into the conception of a general necessity and conformity, neither can it be derived logically from any model of thinking. It cannot be deduced or comprised, it is not transparent. Why is it capricious, unyielding to some, lavish and generous to others? With seeming scorn it turns down the just and promotes the guilty. It is by no means true, "that everything has its deeper significance", as expounded by Hegel in his philosophy of history. There is a pointlessness and incomprehensible cruelty of fate, nowhere better described than by Jacob Burckhardt in his "Luck and Misfortune in History" [3]. Thus, Michael Landmann interpreting adverse fate with today's way of thinking; about which Homer, nearly 3000 years ago wrote in his Iliad about human fate the beautiful metapher

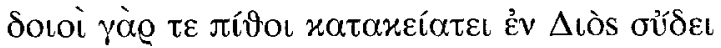

or in Pope's translation of the 18th century:

Two Urns by JOVE's high Throne have ever stood,

The Source of Evil one, and one of Good;

Blessings to these, to those distributes Ills;

To most, he mingles both: The Wretch decreed

To taste the bad, unmix'd, is curst indeed;

Pursu'd by Wrongs, by meagre Famine driv'n, $\mathrm{He}$ wanders, Outcast both of Earth and Heav'n.

Acknowledgements. I am indepted to Miss S. Schönholzer for translation. Prof. E. Ackerknecht for giving most valuable advice and reviewing the manuscript on historical correctness. Prof. $\mathrm{H}$. Koelbing for his valuable suggestions and providing some illustrations.

\section{References}

1. Bergson, H.: L'évolution créatrice. Paris: Felix Alcan, 1917

2. Blum, F.: Über Nebennierendiabetes. Dtsch. Arch. Klin. Med. 71, 146-167 (1901)
3. Burckhardt, J.: Über Glück und Unglück in der Weltgeschichte. In: Weltgeschichtliche Betrachtungen. Stuttgart: Kröner 1969

4. Cannon, W.B.: The way of an investigator. A scientist's experiences in medical research. New York: Norton 1945

5. De Bono, E.: Der Denkprozeß. Hamburg: Rowohlt 1975

6. Floersheim, J. L.: Die medizinische Forschung zwischen Abenteuer und Management. In: Einblick in die Medizin. Basel, Stuttgart: Schwabe 1976

7. Forschbach, J.: Versuche zur Behandlung des Diabetes mellitus mit dem Zuelzer'schen Pankreashormon. Dtsch. Med. Wochenschr. 35, 2053-2055 (1909)

8. Gross, R.: Die Intuition in der ärztlichen Praxis und Forschung. Dtsch. Arztebl. 52, 3500-3502 (1975)

9. Gurova, L. L., Miroshkima, E. A., Polivanova, N. I.: A study in intuitive processes in problem solving (Russian). Vopr. Psikhol. 20, 41-53 (1974)

10. Hartmann, M.: Die philosophischen Grundlagen der Naturwissenschaften. Erkenntnis, Theorie und Methodologie. Jena: Gustav Fischer 1948

11. Jung, C. G.: Psychologische Typen. Zürich: Rascher 1923

12. Kerkhoff, M.: Zum antiken Begriff des Kairos. Z. Philosoph. Forsch. 27, 256-274 (1973)

13. Kleinsorge, A.H.: Die Entdeckung der oralen Antidiabetika. Dtsch. Med. Wochenschr. 101, 467-468 (1976)

14. Laguesse, E.: Importance des îlots endocrines et de leur cycle évolutif dans la physiologie normale et pathologique du pancréas et particulièrement dans le diabète. Presse Med. 18, 449-453 (1910)

15. Landmann, M.: Der rechte Umgang mit dem Schicksal. Universitas 17, 1265-1276 (1962)

16. Leickert, K.H.: Insulinvorläufer - ein historischer Abriß Arzneim. Forsch. 25, 439-442 (1975)

17. Meckauer, W.: Der Intuitionismus und seine Elemente bei Henry Bergson. Dissertation, Breslau 1916

18. Mellinghoff, K.A.: Georg Ludwig Zuelzer's Beitrag zur Insulinforschung. Düsseldorfer Arbeiten zur Geschichte der Medizin, Heft 36. Düsseldorf: Michael Triltsch Verlag 1971

19. Papaspyros, N.S.: The history of diabetes mellitus, 2 nd ed. Stuttgart: Thieme 1964

20. Paracelsus: Collected Papers, vol. I-VIII. Ed. by J. Strebel. St. Gallen: Zollikofer 1945

21. Pasteur, L.: Discours d'ouverture. Faculté de sciences de Lille du 7 déc. 1854. In: René Valléry-Radot: Vie de Pasteur. Paris: Hachette 1900

22. Pope, K. A.: Translation of Homer. The Iliad, Book XXIV, Verse 663-670. Ed by M. Mack. London: Methuen 1967

23. Schadewaldt, H.: Geschichte des Diabetes mellitus. Berlin, Heidelberg, New York: Springer 1975

24. Seckendorf, E.: Kurze Geschichte des Diabetes mellitus. Med. Welt 5, 1443-1445 (1931)

25. Stein, P.: Prioritäten und Prioritätsansprüche ums Insulin. Gesnerus 31, 107-112 (1974)

26. Zuelzer, G.L.: Experimentelle Untersuchungen über den Diabetes. Berl. Klin. Wochenschr. 44, 474-475 (1907)

27. Zuelzer, G.L.: Über Versuche einer spezifischen Fermenttherapie des Diabetes. Z. Exp. Path. Ther. 5, 307-318 (1908)

28. Zuelzer, G.L.: Diskussionsbeitrag zur Diabetesbehandlung mit Insulin. Verh. Dtsch. Ges. Inn. Med. 36, 135-136 (1924)

Prof. A. Labhart

Medizinische Klinik

Departement für Innere Medizin

Kantonsspital

CH-8091 Zürich

Switzerland 